\title{
Biopsy confirmation of metastatic sites in breast cancer patients: clinical impact and future perspectives
}

\author{
Carmen Criscitiello ${ }^{1}$, Fabrice André2,3, Alastair M Thompson ${ }^{4}$, Michele De Laurentiis ${ }^{5}$, Angela Esposito ${ }^{1}$, Lucia Gelao ${ }^{1}$, \\ Luca Fumagalli ${ }^{1}$, Marzia Locatelli ${ }^{1}$, Ida Minchella ${ }^{1}$, Franco Orsi ${ }^{6}$, Aron Goldhirsch ${ }^{1}$ and Giuseppe Curigliano ${ }^{1 *}$
}

\begin{abstract}
Determination of hormone receptor (estrogen receptor and progesterone receptor) and human epidermal growth factor receptor 2 status in the primary tumor is clinically relevant to define breast cancer subtypes, clinical outcome, and the choice of therapy. Retrospective and prospective studies suggest that there is substantial discordance in receptor status between primary and recurrent breast cancer. Despite this evidence and current recommendations, the acquisition of tissue from metastatic deposits is not routine practice. As a consequence, therapeutic decisions for treatment in the metastatic setting are based on the features of the primary tumor. Reasons for this attitude include the invasiveness of the procedure and the unreliable outcome of biopsy, in particular for biopsies of lesions at complex visceral sites. Improvements in interventional radiology techniques mean that most metastatic sites are now accessible by minimally invasive methods, including surgery. In our opinion, since biopsies are diagnostic and changes in biological features between the primary and secondary tumors can occur, the routine biopsy of metastatic disease needs to be performed. In this review, we discuss the rationale for biopsy of suspected breast cancer metastases, review issues and caveats surrounding discordance of biomarker status between primary and metastatic tumors, and provide insights for deciding when to perform biopsy of suspected metastases and which one (s) to biopsy. We also speculate on the future translational implications for biopsy of suspected metastatic lesions in the context of clinical trials and the establishment of bio-banks of biopsy material taken from metastatic sites. We believe that such bio-banks will be important for exploring mechanisms of metastasis. In the future, advances in targeted therapy will depend on the availability of metastatic tissue.
\end{abstract}

\section{Introduction}

Confirmatory biopsy of breast cancer metastases may have many potential benefits: confirming metastatic disease; disclosing non-malignant disease or other primary tumors; and confirming concordance (or discordance) of biological features of disease such as estrogen receptor (ER), progesterone receptor (PgR) and human epidermal growth factor receptor (HER)2 status. Any one of these may contribute to the optimal management of patients with metastatic breast cancer. Discordance in ER, PgR and HER2 status between primary and metastatic breast cancer has been frequently reported [1]. Although evidence for this has

\footnotetext{
* Correspondence: giuseppe.curigliano@ieo.it

${ }^{1}$ Division of Early Drug Development for Innovative Therapies, Istituto

Europeo di Oncologia, Via Ripamonti 435, 20133 Milano, Italia

Full list of author information is available at the end of the article
}

come mostly from retrospective analyses, a few more recent studies have prospectively evaluated the impact of phenotype discordance in patient management (for example, treatment planning) and survival [2]. Re-evaluating the biological features of disease using metastatic lesions has been largely individualized, although recent practice guidelines of the National Comprehensive Cancer Network recommend biopsy of metastatic sites, especially when they represent the first recurrence of disease and/or ER/PgR/ HER2 status is unknown or was originally negative. However, the acquisition of tissue from suspected breast cancer metastases is not always performed in routine practice. Therefore, therapeutic decisions in the metastatic setting are often based on the features of the primary tumor. This often adopted attitude in routine clinical practice is contrary to increasing evidence on the extent and prevalence of 
intra-tumor heterogeneity from advanced sequencing technologies, which have provided insight into the remarkable genetic complexity of cancers [3]. Intra-tumor heterogeneity refers to the existence of subpopulations of cells within a primary tumor and its metastases that have distinct genotypes and phenotypes and may have different biological behaviors [3]. Intra-tumor heterogeneity has implications for cancer therapeutics and biomarker discovery, particularly in the era of personalized medicine, thus ultimately impacting on clinical outcome. In order to better understand the processes that cause intra-tumor heterogeneity and improve patient care and clinical outcomes, clinical trials including comprehensive tissue collection protocols are warranted.

\section{Potential benefits and rationale for biopsying metastatic sites}

Biopsies of breast cancer metastases have many potential benefits. Primarily, biopsying the metastatic site can establish a diagnosis in patients with a single metastasis who were until that time not known to have advanced disease. Biopsies of suspected metastatic lesions can also reveal an unsuspected non-malignant process or other primary cancer. Quite recently, two independent, prospective studies reported on the clinical impact of biopsy of recurrent lesions $[4,5]$. The single-centre Canadian DESTINY study and the multicentre UK Breast Recurrence In Tissues Study (BRITS) revealed non-malignant processes in 3 out of $121(2.5 \%)$ and in 18 out of $205(8.8 \%)$ patients with suspected metastases, respectively $[4,5]$. One woman who participated in the DESTINY study had a second malignancy (0.8\%) [4]. Last but not least, biopsies can corroborate or refute expression of breast cancer-related biomarkers that influence treatment choice.

One of the main reasons supporting the need for biopsies of breast cancer metastases lies in the fact that tissue sampling may be helpful in individualizing therapy

Table 1 Data on discordance of ER, PgR and HER2 status between primary and metastatic breast cancer

\begin{tabular}{|c|c|c|c|}
\hline Reference & ER discordance (\%) & PgR discordance (\%) & HER2 discordance (\%) \\
\hline Lindstrom et al. [7] & 32.4 & 40.7 & 14.5 \\
\hline Niikura et al. [8] & NR & NR & 43 \\
\hline Curigliano et al. [9] & 15 & 49 & 14 \\
\hline Gong et al. [10] & 7 & NR & NR \\
\hline Amir et al. [2] & 12.6 & 31.2 & 5.5 \\
\hline Bogina et al. [11] & 6 & 21 & 1 \\
\hline Wilking et al. [12] & NR & NR & 10 \\
\hline Aitken et al. [13] & 28 & 23 & 9 \\
\hline Amir et al. [4] & 16 & 40.4 & 9.6 \\
\hline Idirisinghe et al. [14] & 16 & 38 & 5 \\
\hline Simmons et al. [15] & 40 & 40 & 8 \\
\hline Liedtke et al. [16] & 18 & 40 & 14 \\
\hline Lower et al. [17] & NR & NR & 33 \\
\hline Broom et al. [18] & 17.7 & 37.3 & 5.5 \\
\hline Santinelli et al. [19] & NR & NR & 18.9 \\
\hline Tapia et al. [20] & NR & NR & 8 \\
\hline Lower et al. [21] & 30 & 39 & NR \\
\hline Carlsson et al. [22] & NR & $N R$ & 0 \\
\hline Edgerton et al. [23] & NR & NR & 15 \\
\hline Gancberg et al. [24] & NR & NR & 9 \\
\hline Simon et al. [25] & NR & NR & 3 \\
\hline Mobbs et al. [26] & 14 & 28 & NR \\
\hline Guarneri et al. [27] & 22 & 36 & 16 \\
\hline Hoefnagel et al. [28] & 10.3 & 30 & 5.2 \\
\hline Thompson et al. [5] & 10.2 & 24.8 & 2.9 \\
\hline Brogi et al. [29] & 16.2 & 20.6 & 5 \\
\hline Chang et al. [30] & 25 & NR & 12.5 \\
\hline
\end{tabular}

ER, estrogen receptor; HER, human epidermal growth factor receptor; NR, not reported; PgR, progesterone receptor. 
according to the profile of metastatic disease rather than the primary tumor. The discordance in ER, PgR and HER2 receptor status between primary and metastatic breast cancer has been constantly reported [1] (Table 1). This evidence has been mostly derived from retrospective analyses investigating ER, PgR and HER2 status in heterogeneous sites of relapse [1]. Recently, a meta-analysis showed that the rates of discordance for ER, PgR and HER2 status were $20 \%, 33 \%$ and $8 \%$, respectively [6].

Two alternative explanations may justify this observation: technical issues, including poor reproducibility of the immunohistochemical technique, or actual tumor heterogeneity. The lack of perfect reproducibility in the assessment of ER, PgR and HER2 status has been described in prospective trials based on central pathology review $[31,32]$, and a mathematical model has been proposed foreseeing a discordance rate of at least 10\% even using an ideal test yielding $95 \%$ accuracy, sensitivity and specificity, a scenario reasonably far from clinical practice, where additional variables may further affect reproducibility [33]. Very likely the technical issue on its own does not completely explain the discrepancy in ER, PgR and HER2 status between primary tumors and relapses, as we would likely observe roughly the same discordance rates for ER, PgR and HER2 status, which is not the case [6]. Moreover, the conversion to negative receptor status is, on average, higher than the positive conversion (24\% versus $14 \%$ for ER, $46 \%$ versus $15 \%$ for $\mathrm{PgR}$, and $13 \%$ versus $5 \%$ for HER2); these would be expected to be similar if occurring by chance or for technical reasons [6]. This observation might be explained by the occurrence of mechanisms of resistance, perhaps as the result of selection fostering ER-, PgR- and HER2-negative tumor clones in the metastases. On the other hand, recent studies based on nextgeneration sequencing have shed new light on tumor heterogeneity, reinforcing the hypothesis that variation in ER, PgR and HER2 status may actually reflect clonal genome evolution. Tumor heterogeneity may be attributable to tumor biological drift, selective pressures of therapy leading to clonal selection with development of a novel tumor cell clone, or presence of small subclones routinely undetected within the primary tumor [3].

In the era of personalized medicine, biopsies may also improve selection of patients for targeted therapy trials. There is a considerable lack of understanding of metastasis biology due to the imbalance between the abundance of tissue from primary tumors and no cultures of metastasis biopsies. This has led to the assumption that lessons from primary breast cancer extend to metastatic breast cancer. Despite the large number of papers published on the role of genome sequencing in breast cancer, just two $[34,35]$ have focused on the metastatic site, while all the others have focused on primary breast cancer. Communally, 900 primary breast cancers have been sequenced versus 10 breast cancer metastases. The characterization of metastatic breast cancer has been systematically neglected because of the difficulties culturing metastasis biopsies. Hence, it is important to change attitudes in order to better understand how metastases determine outcome in breast cancer. Potentially, we can detect substantial genomic evolution between a primary tumor and its metastases. All existing methods of classifying breast cancer are predicated on primary breast cancer. However, many metastatic-specific mutations do exist, many of which may be driver mutations that could be targeted by drugs, but unless biopsy of metastasis is performed we will not be able to identify these relevant molecular targets.

\section{Safety of the procedure and logistical considerations}

Biopsy cannot always be performed safely for the patient. Generally, biopsy of metastases in patients with breast cancer is carried out by percutaneous image-guided biopsy, which is safe, effective, and is associated with minimal complications and patient discomfort. The Society of Interventional Radiology reports a threshold of $2 \%$ for major complications [36]. Generic complications include bleeding, infection, perforation, and unintended organ injury. Moreover, organ-specific complications associated with biopsy can occur, such as hematuria with kidney biopsy or pneumothorax with lung biopsy. Tumor seeding after biopsy is very rare [37]. At the 2013 ASCO annual meeting, Dr André reported that biopsy was complicated by a serious adverse event in 9 out of 423 patients within the SAFIR01 trial [38]. The acceptance, feasibility and safety of sequential biopsies have been studied in the field of clinical trials [39]. Additionally, iterative biopsies may lead to delay in treatment in patients with metastatic breast cancer [4]. Finally, it has to be acknowledged that this procedure is financially expensive.

\section{Treatment changes according to biopsy of the metastasis}

Few studies have reported treatment changes based on analysis of metastases (Table 2). In a pooled analysis of the prospective BRITS and DESTINY studies, biopsy results altered management in $14.2 \%$ of cases but the clinical impact is unknown [2]. Modification of therapy was more common when there was gain of receptor expression. Gain of HER2 amplification resulted in a change of therapy in 11 patients, and gain of hormone receptor expression resulted in a change of therapy in 9 patients. Loss of HER2 amplification led to a change in therapy in 1 patient, and loss of hormone receptor expression led to a change of therapy in 11 patients [2]. Overall, biomarker evaluation of metastasis within prospective clinical trials led to therapeutic changes in 17 to $20 \%$ of patients $[4,5,15]$. Loss or gain of biomarker expression between primary tumor and metastasis may not 
Table 2 Change in management based on biopsy

\begin{tabular}{lcc}
\hline Reference & Number of patients & Therapy changed (\%) \\
\hline Lindstrom et al. [7] & 1,010 & 23 (HER2) 50 (ER) \\
Curigliano et al. [9] & 255 & 12.1 \\
Amir et al. [2] & 289 & 14.2 \\
Bogina et al. [11] & 140 & 7.3 \\
Amir et al. [4] & 121 & 14 \\
Simmons et al. [15] & 40 & 20 \\
Thompson et al. [5] & 137 & 17.5 \\
\hline
\end{tabular}

ER, estrogen receptor; HER2, human epidermal growth factor receptor 2.

have the same therapeutic impact. Changing therapy based on loss of a biomarker could avoid the prescription of an unnecessary treatment with potential toxicity for the patient, but data are not robust enough to affirm that an agent should be discontinued based on a new biopsy of the metastasis. Conversely, gain of a biomarker could offer the possibility to adopt new therapies but this event is relatively rare. Importantly, we have to highlight that the impact on survival of biopsy-driven treatment has not been reported to date in a prospective randomized trial.

\section{Which metastasis to biopsy and when?}

Breast cancer metastases have been poorly studied systematically, with usually only one of a breast cancer patient's metastases biopsied with small tissue sample (s). Whether the capacity to metastasize is an intrinsic property of the tumor or an acquired feature, and whether all cells in a primary tumor are capable of metastasis or just a small subset (subclone) are unknown. It is debatable whether different metastases in the same patient are biologically different, perhaps as a result of selection pressures. To address this issue, autopsy data prospectively comparing primary tumor to paired multiple metastatic sites from eight patients found noticeable similarities in terms of gene expression profiles, suggesting that metastatic capability was an intrinsic property of the primary tumor and not based on clonal selection [40]. Another study compared the expression of biomarkers between primary tumors and their paired metastases and among different metastases from the same patient; this study used archived primary breast cancer and multiple different metastases collected at autopsy from 10 consenting patients [41]. It revealed consistency in ER, PgR and HER2 expression in different metastases even if this was different to the expression in the synchronous primary cancer [41].

Even assuming clinical and genomic heterogeneity across metastases [3], we cannot sample all lesions, clones or genomes in a single patient, as the cost-benefit ratio would be too high. When proposing a biopsy to a patient, we need to consider patient risk, inconvenience and discomfort, although it has been reported that 51\% of patients would altruistically consider having biopsies for research purposes only with no clinical implications, even knowing the risks, and $72 \%$ would consider having additional biopsies to provide more material for research [42]. Also, there are fiscal implications related to sampling and analysis, although the economic burden of metastatic breast cancer is overall remarkable in terms of monetary cost [43].

Pragmatically, a valid strategy could consist of biopsying and analyzing the first metastasis and, accordingly, selecting the subsequent treatment. Thereafter, for resistant or relapsing lesions, further biopsy may be considered. Where cancer cells cannot be eliminated with a single course of therapy, several steps may be required considering individual clones and subclones within the tumor. The timing of tumor reappearance should also be considered as a variable to support biopsy of metastasis. For late recurrences of ER + breast cancers, the 'tumor dormancy' scenario, there is a medical need for confirmatory biopsy to ascertain histology.

\section{Acquired resistance and biopsy of metastases}

Treatment exposure may change the molecular profile of a tumor and this can be assessed by performing biopsy of the metastatic site. Challenges to targeted therapies include acquired and primary resistance. Acquired resistance may develop in most patients with metastatic breast cancer [44]. Some mechanisms by which a tumor stops responding to a given therapy that it had initially responded to have been identified in HER2+ tumors. These include loss of expression of the target as a result of continuous therapy [45], activation of mutations downstream of the target itself, and activation of additional mechanisms that promote cell proliferation [46]. Primary resistance may occur due to lack of target dependency. Furthermore, activation of compensatory pathways may rescue cells from the inhibitory effects of blocking just one target or pathway.

While treatment of HER2+ breast cancer with the HER2targeted monoclonal antibody trastuzumab has demonstrated significant improvements in patient outcome, nearly $70 \%$ of patients with HER $2+$ breast cancer demonstrate resistance to trastuzumab in the metastatic setting [47-49]. Several mechanisms have been implicated in resistance to trastuzumab, including increased signaling mediated by growth factor receptors, alterations of the HER2 receptor, phosphatase and tensin homolog (PTEN) loss, and aberrant activity of the phosphatidylinositide 3-kinase (PI3K)/ mammalian target of rapamycin (mTOR) pathway. Quite recently, contrary to some preclinical and a few clinical studies suggesting a decrease in trastuzumab sensitivity in patients with PTEN- tumors, Perez and colleagues [50] showed that HER2+ breast cancer patients benefit from adjuvant trastuzumab regardless of tumor PTEN status. Therefore, inhibition of the PI3K/Akt/mTOR pathway with 
a mTOR inhibitor such as everolimus might be a reasonable approach to overcome resistance and restore sensitivity to trastuzumab-based therapy. This hypothesis is supported by preclinical studies in which PI3K inhibitors overcame PTEN loss-induced trastuzumab resistance and slowed the growth of HER2+ breast cancer cells in vitro and in vivo [51,52]. Such a therapeutic approach has been adopted in the BOLERO-3 (Breast Cancer Trials of Oral Everolimus) clinical trial, in which the addition of everolimus to trastuzumab and vinorelbine significantly prolonged progressionfree survival in patients with HER2+ metastatic breast cancer resistant to trastuzumab, as presented by Dr O'Regan during the 2013 ASCO annual meeting (unpublished observations, Ruth O'Regan).

Similarly, mutation frequencies in the ER gene (ESR1) differ between primary and metastatic tumors, as seen through large-scale next-generation sequencing of postmenopausal women with ER + metastatic breast cancer treated with everolimus in combination with exemestane within the BOLERO-2 trial, as presented by Dr Piccart at the 2013 IMPAKT meeting (unpublished observations, Martine Piccart). The BOLERO-2-based dataset indicated enrichment in ESR1 gene mutations from primary tumor samples (7\%) compared with metastatic tumor samples (19\%). These mutations appear to cluster in the ligand-binding domain, so are probably affecting the binding of estrogen, rendering these tumors likely estrogen-independent.

In such a context, the role of biopsy is crucial to develop drugs that aim at reversing resistance, based on protein assessment of the metastasis. This concept is in contrast to the current concept of 'oncogene de-addiction', according to which the oncogenic targets need to be present on the primary tumor. Thus, on one hand the biopsy of the primary tumor may be helpful to develop therapies that aim to de-addict to oncogenes, and on the other biopsy of metastases may be helpful to develop drugs that aim at reversing resistance.

\section{The role of biopsy for research purposes}

Current molecular oncology technology enables us to characterize the complete mutational landscape of cancers $[53,54]$. This holds great promise with regard to understanding driving genetic aberrations, discovering new therapeutic targets, elucidating tumor genetic heterogeneity and ultimately improving outcomes for cancer patients. Recent studies using massively parallel sequencing have uncovered a large number of potential 'driver' mutations that occur at a low frequency but are potentially targetable by agents that are currently available for other clinical indications or for possible breast cancer clinical trials [53,54].

Breast cancer metastases often acquire new molecular aberrations, and different treatment-resistant clones may emerge over time. While the clinical relevance of these phenomena is not yet well understood, it suggests that metastatic lesions should be biopsied to recover the genomic portrait of advanced breast cancers, and that treatment decisions could conceivably be based on these molecular profiles, rather than those of the primary tumors. To this end, the Breast International Group (BIG) is constructing a molecular screening program called PRISM-BC that will facilitate the large-scale screening and sequencing of metastatic breast cancer patients, using metastatic biopsies, to determine which patients would be eligible for phase II downstream therapeutic clinical trials conducted under the BIG umbrella using novel targeted agents. In this context, the French SAFIR02 program (NCT01414933) aims at demonstrating the medical benefits of treatment based on genomic analysis. Only a small proportion of these patients will be identified with putative 'actionable' mutations, with the vast majority having 'non-actionable' mutations; BIG is committed to building an important research program based on the follow-up of screened but trial-ineligible patients to advance our knowledge of metastatic breast cancer.

\section{The liquid biopsy}

Tumors are heterogeneous and continuously evolve. Evolutionary changes within the cancer can alter the mutational spectrum of the disease and the responsiveness of the cancer to therapies. This may necessitate repeat biopsies [55]. However, repeat biopsies are difficult, invasive, costly and somewhat limited in that they provide a picture of mutations present only at a given time and organ site [55]. Recent studies have shown that genomic alterations in solid cancers can be characterized by massively parallel sequencing of circulating cell-free tumor DNA released from cancer cells into plasma, representing a non-invasive liquid biopsy. For some applications, mutation detection in plasma DNA could potentially replace invasive biopsies as a means to assess tumor genetic characteristics [55].

Genome-wide sequencing of plasma samples demonstrates comprehensive coverage of the genome [56]. More recently, genome-wide sequencing of plasma DNA has been demonstrated as a potential tool for detection of disease or analysis of tumor burden in patients with advanced cancers [55,57]. These studies have established that plasma DNA can represent the entire tumor genome [57]. However, identifying somatic mutations in cell-free tumor DNA is expensive and technically challenging.

Analysis of isolated circulating tumor cells (CTCs) has also been proposed. Characterization of CTCs could be used to predict treatment response and personalize cancer treatments [58]. However, isolation and characterization of CTCs is expensive and technically demanding [58]. Moreover, CTCs are not always present and may represent a different fraction of cells from the bulk metastatic 
tissue. While (serial) blood samples could be an interesting alternative to biopsies of metastatic lesions, we do not yet consider circulating DNA or CTCs as the solution to all our needs. Such an approach is useful for genomics, but does not inform on in situ transcriptome, proteome, lymphocytic infiltration or microenvironmental cues.

\section{Conclusion}

The well-documented heterogeneity in the primary tumor supports the need for biopsy of one or more metastases. While biopsy of the metastatic site may not be prospectively able to demonstrate improved outcome for each patient - at least for the time being - it is paramount to introduce a culture of systematically biopsying metastases in order to gain information on the biology of the disease and, accordingly, select the best treatment option for our patients. This attitude is being introduced at present in clinical trials and may in future become standard clinical practice.

Hopefully, application of improved technology will ultimately translate into improved outcome. In this scenario, biomarker-driven clinical trials with targeted agents for patients with metastatic breast cancer with relatively rare but 'actionable' mutations may became crucial and biopsy of the metastatic tissues will be essential. We expect that future clinical trials will increasingly require metastatic tissue to be obtained to assess molecular differences, not only at the receptor level but also at the DNA, RNA, protein, and functional pathway levels. Most current target-driven therapeutic interventional trials will be developed according to a specific molecular profile.

The metastases could also be biopsied soon after initiation of treatment to determine by pharmacodynamic endpoints whether the disease is responding and whether treatment should be continued or discontinued or additional treatments should be added. At disease progression, biopsy of metastatic sites will be performed to elucidate the molecular changes contributing to treatment resistance, which may help to determine the next treatment choices.

Routine sampling of metastatic tissue will give us the opportunity to establish bio-banks of biopsy material taken from metastatic sites. Such biobanks will be important for exploring mechanisms of metastasis. In the future, advances in targeted therapy will depend on the availability of such metastatic tissue. We need to advance translational research by using analysis of metastatic tissue to design appropriate targeted therapy for patients with metastatic disease and ultimately for patient benefit.

\section{Abbreviations}

BIG: Breast International Group; BRITS: Breast Recurrence In Tissues Study; CTC: Circulating tumor cell; ER: Estrogen receptor; HER: Human epidermal growth factor receptor; mTOR: Mammalian target of rapamycin; PgR: Progesterone receptor; PI3K: Phosphatidylinositide 3-kinase; PTEN: Phosphatase and tensin homolog.

Competing interests

The authors declare that they have no competing interests.

Authors' contributions

CC and GC designed the study, collected and analyzed the data, and wrote the manuscript. FA, AMT, MDL, FO and AG read and critically revised the manuscript. All authors read and approved the final manuscript.

\section{Author details}

${ }^{1}$ Division of Early Drug Development for Innovative Therapies, Istituto Europeo di Oncologia, Via Ripamonti 435, 20133 Milano, Italia. ${ }^{2}$ INSERM Unit U981, Gustave Roussy Institut, Villejuif 94805, France. ${ }^{3}$ Department of Medical Oncology, Gustave Roussy Institute, Villejuif 94805, France. ${ }^{4}$ Dundee Cancer Centre, Ninewells Hospital and Medical School, University of Dundee, Clinical Research Centre Building, Dundee DD1 9SY, UK. ${ }^{5}$ Department of Breast Oncology, Istituto nazionale Tumori 'Fondazione Pascale', via Mariano Semmola, 80131 Napoli, Italia. ${ }^{6}$ Unit of Interventional Radiology, Istituto Europeo di Oncologia, Via Ripamonti 435, 20133 Milano, Italia.

\section{Published: 21 Mar 2014}

\section{References}

1. Vignot S, Besse B, Andre F, Spano JP, Soria JC: Discrepancies between primary tumor and metastasis: a literature review on clinically established biomarkers. Crit Rev Oncol Hematol 2012, 84:301-313.

2. Amir E, Clemons M, Purdie CA, Miller N, Quinlan P, Geddie W, Coleman RE, Freedman OC, Jordan LB, Thompson AM: Tissue confirmation of disease recurrence in breast cancer patients: pooled analysis of multi-centre, multi-disciplinary prospective studies. Cancer Treat Rev 2012, 38:708-714.

3. Fisher R, Pusztai L, Swanton C: Cancer heterogeneity: implications for targeted therapeutics. Br J Cancer 2013, 108:479-485.

4. Amir E, Miller N, Geddie W, Freedman O, Kassam F, Simmons C, Oldfield M, Dranitsaris G, Tomlinson G, Laupacis A, Tannock IF, Clemons M: Prospective study evaluating the impact of tissue confirmation of metastatic disease in patients with breast cancer. J Clin Oncol 2012, 30:587-592.

5. Thompson AM, Jordan LB, Quinlan P, Anderson E, Skene A, Dewar JA, Purdie CA: Prospective comparison of switches in biomarker status between primary and recurrent breast cancer: the breast recurrence in tissues study (BRITS). Breast Cancer Res 2010, 12:R92.

6. Aurilio G, Monfardini L, Rizzo S, Sciandivasci A, Preda L, Bagnardi V, Disalvatore D, Pruneri G, Munzone E, Della Vigna P, Renne G, Bellomi M, Curigliano G, Goldhirsch A, Nolè F: Discordant hormone receptor and human epidermal growth factor receptor 2 status in bone metastases compared to primary breast cancer. Acta Oncol 2013, 52:1649-1656.

7. Lindstrom LS, Karlsson E, Wilking UM, Johansson U, Hartman J, Lidbrink EK, Hatschek T, Skoog L, Bergh J: Clinically used breast cancer markers such as estrogen receptor, progesterone receptor, and human epidermal growth factor receptor 2 are unstable throughout tumor progression. J Clin Oncol 2012, 30:2601-2608.

8. Niikura N, Liu J, Hayashi N, Mittendorf EA, Gong Y, Palla SL, Tokuda Y, Gonzalez-Angulo AM, Hortobagyi GN, Ueno NT: Loss of human epidermal growth factor receptor 2 (HER2) expression in metastatic sites of HER2overexpressing primary breast tumors. J Clin Oncol 2012, 30:593-599.

9. Curigliano G, Bagnardi V, Viale G, Fumagalli L, Rotmensz N, Aurilio G, Locatelli M, Pruneri G, Giudici S, Bellomi M, Della Vigna P, Monfardini L, Orsi F, Nolè F, Munzone E, Goldhirsch A: Should liver metastases of breast cancer be biopsied to improve treatment choice? Ann Oncol 2011, 22:2227-2233

10. Gong Y, Han EY, Guo M, Pusztai L, Sneige N: Stability of estrogen receptor status in breast carcinoma: a comparison between primary and metastatic tumors with regard to disease course and intervening systemic therapy. Cancer 2011, 117:705-713.

11. Bogina G, Bortesi L, Marconi M, Venturini M, Lunardi G, Coati F, Massocco A, Manfrin E, Pegoraro C, Zamboni G: Comparison of hormonal receptor and HER-2 status between breast primary tumours and relapsing tumours: 
clinical implications of progesterone receptor loss. Virchows Arch 2011, 459:1-10.

12. Wilking U, Karlsson E, Skoog L, Hatschek T, Lidbrink E, Elmberger G, Johansson $H$, Lindstrom L, Bergh J: HER2 status in a population-derived breast cancer cohort: discordances during tumor progression. Breast Cancer Res Treat 2011, 125:553-561.

13. Aitken SJ, Thomas JS, Langdon SP, Harrison DJ, Faratian D: Quantitative analysis of changes in ER, PR and HER2 expression in primary breast cancer and paired nodal metastases. Ann Oncol 2010, 21:1254-1261.

14. Idirisinghe PK, Thike AA, Cheok PY, Tse GM, Lui PC, Fook-Chong S, Wong NS, Tan PH: Hormone receptor and c-ERBB2 status in distant metastatic and locally recurrent breast cancer. Pathologic correlations and clinical significance. Am J Clin Pathol 2010, 133:416-429.

15. Simmons C, Miller N, Geddie W, Gianfelice D, Oldfield M, Dranitsaris G, Clemons $\mathrm{MU}$ : Does confirmatory tumor biopsy alter the management of breast cancer patients with distant metastases? Ann Oncol 2009, 20:1499-1504

16. Liedtke C, Broglio K, Moulder S, Hsu L, Kau SW, Symmans WF, Albarracin C, Meric-Bernstam F, Woodward W, Theriault RL, Kiesel L, Hortobagyi GN, Pusztai L, Gonzalez-Angulo AM: Prognostic impact of discordance between triple-receptor measurements in primary and recurrent breast cancer. Ann Oncol 2009, 20:1953-1958.

17. Lower EE, Glass E, Blau R, Harman S: HER-2/neu expression in primary and metastatic breast cancer. Breast Cancer Res Treat 2009, 113:301-306.

18. Broom RJ, Tang PA, Simmons C, Bordeleau L, Mulligan AM, O'Malley FP, Miller N, Andrulis IL, Brenner DM, Clemons MJ: Changes in estrogen receptor, progesterone receptor and Her-2/neu status with time: discordance rates between primary and metastatic breast cancer. Anticancer Res 2009, 29:1557-1562.

19. Santinelli A, Pisa E, Stramazzotti D, Fabris G: HER-2 status discrepancy between primary breast cancer and metastatic sites. Impact on target therapy. Int J Cancer 2008, 122:999-1004.

20. Tapia C, Savic S, Wagner U, Schönegg R, Novotny H, Grilli B, Herzog M, Barascud AD, Zlobec I, Cathomas G, Terracciano L, Feichter G, Bubendorf L: HER2 gene status in primary breast cancers and matched distant metastases. Breast Cancer Res 2007, 9:R31.

21. Lower EE, Glass EL, Bradley DA, Blau R, Heffelfinger S: Impact of metastatic estrogen receptor and progesterone receptor status on survival. Breast Cancer Res Treat 2005, 90:65-70.

22. Carlsson J, Nordgren H, Sjostrom J, Wester K, Villman K, Bengtsson NO, Ostenstad B, Lundqvist $\mathrm{H}$, Blomqvist C: HER2 expression in breast cancer primary tumours and corresponding metastases. Original data and literature review. Br J Cancer 2004, 90:2344-2348.

23. Edgerton SM, Moore D 2nd, Merkel D, Thor AD: erbB-2 (HER-2) and breast cancer progression. Appl Immunohistochem Mol Morphol 2003, 11:214-221.

24. Gancberg D, Di Leo A, Cardoso F, Rouas G, Pedrocchi M, Paesmans M, Verhest A, Bernard-Marty C, Piccart MJ, Larsimont D: Comparison of HER-2 status between primary breast cancer and corresponding distant metastatic sites. Ann Oncol 2002, 13:1036-1043.

25. Simon R, Nocito A, Hübscher T, Bucher C, Torhorst J, Schraml P, Bubendorf L Mihatsch MM, Moch H, Wilber K, Schötzau A, Kononen J, Sauter G: Patterns of her-2/neu amplification and overexpression in primary and metastatic breast cancer. J Natl Cancer Inst 2001, 93:1141-1146.

26. Mobbs BG, Fish EB, Pritchard Kl, Oldfield G, Hanna WH: Estrogen and progesterone receptor content of primary and secondary breast carcinoma: influence of time and treatment. Eur J Cancer Clin Oncol 1987, 23:819-826.

27. Guarneri V, Giovannelli S, Ficarra G, Bettelli S, Maiorana A, Piacentini F, Barbieri E, Dieci MV, D'Amico R, Jovic G, Conte P: Comparison of HER-2 and hormone receptor expression in primary breast cancers and asynchronous paired metastases: impact on patient management. Oncologist 2008, 13:838-844.

28. Hoefnagel LD, van de Vijver MJ, van Slooten HJ, Wesseling P, Wesseling J, Westenend PJ, Bart J, Seldenrijk CA, Nagtegaal ID, Oudejans J, van der Valk P, van der Groep P, de Vries EG, van der Wall E, van Diest PJ: Receptor conversion in distant breast cancer metastases. Breast Cancer Res 2010, 12:R75

29. Brogi E, Murphy CG, Johnson ML, Conlin AK, Hsu M, Patil S, Akram M, Nehhozina T, Jhaveri KL, Hudis CA, Seidman AD: Breast carcinoma with brain metastases: clinical analysis and immunoprofile on tissue microarrays. Ann Oncol 2011, 22:2597-2603.

30. Chang HJ, Han SW, Oh DY, Im SA, Jeon YK, Park IA, Han W, Noh DY, Bang YJ, Kim TY: Discordant human epidermal growth factor receptor 2 and hormone receptor status in primary and metastatic breast cancer and response to trastuzumab. Jpn J Clin Oncol 2011, 41:593-599.
31. Viale G, Regan MM, Maiorano E, Mastropasqua MG, Dell'Orto P, Rasmussen BB, Raffoul J, Neven P, Orosz Z, Braye S, Ohlschlegel C, Thürlimann B, Gelber RD, Castiglione-Gertsch M, Price KN, Goldhirsch A, Gusterson BA, Coates AS: Prognostic and predictive value of centrally reviewed expression of estrogen and progesterone receptors in a randomized trial comparing letrozole and tamoxifen adjuvant therapy for postmenopausal early breast cancer: BIG 1-98. J Clin Oncol 2007, 25:3846-3852.

32. Perez EA, Suman VJ, Davidson NE, Martino S, Kaufman PA, Lingle WL, Flynn PJ, Ingle JN, Visscher D, Jenkins RB: HER2 Testing by local, central, and reference laboratories in specimens from the north central cancer treatment group N9831 intergroup adjuvant trial. J Clin Oncol 2006, 24:3032-3038.

33. Pusztai L, Viale G, Kelly CM, Hudis CA: Estrogen and HER-2 receptor discordance between primary breast cancer and metastasis. Oncologist 2010, 15:1164-1168.

34. Shah SP, Morin RD, Khattra J, Prentice L, Pugh T, Burleigh A, Delaney A, Gelmon K, Guliany R, Senz J, Steidl C, Holt RA, Jones S, Sun M, Leung G, Moore R, Severson T, Taylor GA, Teschendorff AE, Tse K, Turashvili G, Varhol R, Warren RL, Watson P, Zhao Y, Caldas C, Huntsman D, Hirst M, Marra MA, Aparicio S: Mutational evolution in a lobular breast tumour profiled at single nucleotide resolution. Nature 2009, 461:809-813.

35. Ding L, Ellis MJ, Li S, Larson DE, Chen K, Wallis JW, Harris CC, McLellan MD, Fulton RS, Fulton LL, Abbott RM, Hoog J, Dooling DJ, Koboldt DC, Schmidt H, Kalicki J, Zhang Q, Chen L, Lin L, Wendl MC, McMichael JF, Magrini VJ, Cook L, McGrath SD, Vickery TL, Appelbaum E, Deschryver K, Davies S, Guintoli T, Lin L, et al: Genome remodelling in a basal-like breast cancer metastasis and xenograft. Nature 2010, 464:999-1005.

36. Gupta S, Wallace MJ, Cardella JF, Kundu S, Miller DL, Rose SC: Quality improvement guidelines for percutaneous needle biopsy. J Vasc Interv Radiol 2010, 21:969-975.

37. Liebens F, Carly B, Cusumano P, Van Beveren M, Beier B, Fastrez M, Rozenberg S: Breast cancer seeding associated with core needle biopsies: a systematic review. Maturitas 2009, 62:113-123.

38. André F, Bachelot T, Commo F, Campone M, Arnedos M, Dieras V, Lacroix-Triki M, Lacroix L, Cohen P, Gentien D, Adélaide J, Dalenc F, Goncalves A, Levy C, Ferrero J-M, Bonneterre B, Lefeuvre C, Jimenez M, Filleron T, Bonnefoi H: Comparative genomic hybridisation array and DNA sequencing to direct treatment of metastatic breast cancer: a multicentre, prospective trial (SAFIR01/UNICANCER). Lancet Oncol 2014, 15:267-274.

39. Gomez-Roca CA, Lacroix L, Massard C, De Baere T, Deschamps F, Pramod R, Bahleda R, Deutsch E, Bourgier C, Angevin E, Lazar V, Ribrag V, Koscielny S, Chami L, Lassau N, Dromain C, Robert C, Routier E, Armand JP, Soria JC: Sequential research-related biopsies in phase I trials: acceptance, feasibility and safety. Ann Oncol 2012, 23:1301-1306.

40. Weigelt B, Glas AM, Wessels LF, Witteveen AT, Peterse JL, van't Veer LJ: Gene expression profiles of primary breast tumors maintained in distant metastases. Proc Natl Acad Sci U S A 2003, 100:15901-15905.

41. Wu JM, Fackler MJ, Halushka MK, Molavi DW, Taylor ME, Teo WW, Griffin C, Fetting J, Davidson NE, De Marzo AM, Hicks JL, Chitale D, Ladanyi M, Sukumar S, Argani P: Heterogeneity of breast cancer metastases: comparison of therapeutic target expression and promoter methylation between primary tumors and their multifocal metastases. Clin Cancer Res 2008, 14:1938-1946.

42. Seah DS, Scott SM, Najita J, Openshaw T, Krag K, Frank E, Sohl J, Stadler ZK, Garrett M, Silverman SG, Peppercorn J, Winer EP, Come SE, Lin NU: Attitudes of patients with metastatic breast cancer toward research biopsies. Ann Oncol 2013, 24:1853-1859.

43. Montero AJ, Eapen S, Gorin B, Adler P: The economic burden of metastatic breast cancer: a U.S. managed care perspective. Breast Cancer Res Treat 2012, 134:815-822.

44. Wong ST, Goodin S: Overcoming drug resistance in patients with metastatic breast cancer. Pharmacotherapy 2009, 29:954-965.

45. Mittendorf EA, Wu Y, Scaltriti M, Meric-Bernstam F, Hunt KK, Dawood S, Esteva FJ, Buzdar AU, Chen H, Eksambi S, Hortobagyi GN, Baselga J, Gonzalez-Angulo AM: Loss of HER2 amplification following trastuzumab-based neoadjuvant systemic therapy and survival outcomes. Clin Cancer Res 2009, 15:7381-7388.

46. Scaltriti M, Eichhorn PJ, Cortés J, Prudkin L, Aura C, Jiménez J, Chandarlapaty S, Serra V, Prat A, Ibrahim YH, Guzmán M, Gili M, Rodríguez O, Rodríguez S, Pérez J, Green SR, Mai S, Rosen N, Hudis C, Baselga J: Cyclin E amplification/ overexpression is a mechanism of trastuzumab resistance in HER2+ breast cancer patients. Proc Natl Acad Sci USA 2011, 108:3761-3766.

47. Bender LM, Nahta R: Her2 cross talk and therapeutic resistance in breast cancer. Front Biosci 2008, 13:3906-3912. 
48. Higgins MJ, Baselga J: Targeted therapies for breast cancer. J Clin Investig 2011, 121:3797-3803.

49. Steelman LS, Chappell WH, Abrams SL, Kempf RC, Long J, Laidler P, Mijatovic S, Maksimovic-Ivanic D, Stivala F, Mazzarino MC, Donia M, Fagone P, Malaponte G, Nicoletti F, Libra M, Milella M, Tafuri A, Bonati A, Bäsecke J, Cocco L, Evangelisti C, Martelli AM, Montalto G, Cervello M, McCubrey JA: Roles of the Raf/MEK/ERK and PI3K/PTEN/Akt/mTOR pathways in controlling growth and sensitivity to therapy-implications for cancer and aging. Aging 2011, 3:192-222.

50. Perez EA, Dueck AC, McCullough AE, Chen B, Geiger XJ, Jenkins RB, Lingle WL, Davidson NE, Martino S, Kaufman PA, Kutteh LA, Sledge GW, Harris LN, Gralow JR, Reinholz MM: Impact of PTEN protein expression on benefit from adjuvant Trastuzumab in early-stage human epidermal growth factor receptor 2-positive breast cancer in the north central cancer treatment group N9831 trial. J Clin Oncol 2013, 31:2115-2122.

51. Lu CH, Wyszomierski SL, Tseng LM, Sun MH, Lan KH, Neal CL, Mills GB, Hortobagyi GN, Esteva FJ, Yu D: Preclinical testing of clinically applicable strategies for overcoming trastuzumab resistance caused by PTEN deficiency. Clin Cancer Res 2007, 13:5883-5888.

52. Nagata Y, Lan KH, Zhou X, Tan M, Esteva FJ, Sahin AA, Klos KS, Li P, Monia BP, Nguyen NT, Hortobagyi GN, Hung MC, Yu D: PTEN activation contributes to tumor inhibition by trastuzumab, and loss of PTEN predicts trastuzumab resistance in patients. Cancer cell 2004, 6:117-127.

53. Andre F, Job B, Dessen P, Tordai A, Michiels S, Liedtke C, Richon C, Yan K, Wang B, Vassal G, Delaloge S, Hortobagyi GN, Symmans WF, Lazar V, Pusztai L: Molecular characterization of breast cancer with high-resolution oligonucleotide comparative genomic hybridization array. Clin Cancer Res 2009, 15:441-451.

54. Stephens PJ, Tarpey PS, Davies H, Van Loo P, Greenman C, Wedge DC, NikZainal S, Martin S, Varela I, Bignell GR, Yates LR, Papaemmanuil E, Beare D, Butler A, Cheverton A, Gamble J, Hinton J, Jia M, Jayakumar A, Jones D, Latimer C, Lau KW, McLaren S, McBride DJ, Menzies A, Mudie L, Raine K, Rad R Chapman MS, Teague J, et al: The landscape of cancer genes and mutational processes in breast cancer. Nature 2012, 486:400-404.

55. Forshew T, Murtaza M, Parkinson C, Gale D, Tsui DW, Kaper F, Dawson SJ, Piskorz AM, Jimenez-Linan M, Bentley D, Hadfield J, May AP, Caldas C, Brenton JD, Rosenfeld N: Noninvasive identification and monitoring of cancer mutations by targeted deep sequencing of plasma DNA. Sci Trans/ Med 2012, 4:136-168.

56. Lo YM, Chan KC, Sun H, Chen EZ, Jiang P, Lun FM, Zheng YW, Leung TY, Lau TK, Cantor CR, Chiu RW: Maternal plasma DNA sequencing reveals the genomewide genetic and mutational profile of the fetus. Sci Transl Med 2010, 2:61-91.

57. Leary RJ, Sausen M, Kinde I, Papadopoulos N, Carpten JD, Craig D,

O'Shaughnessy J, Kinzler KW, Parmigiani G, Vogelstein B, Diaz LA Jr, Velculescu VE: Detection of chromosomal alterations in the circulation of cancer patients with whole-genome sequencing. Sci Trans/ Med 2012, 4:162-154

58. Onstenk W, Gratama JW, Foekens JA, Sleiffer S: Towards a personalized breast cancer treatment approach guided by circulating tumor cell (CTC) characteristics. Cancer Treat Rev 2013, 39:691-700.

$10.1186 / \mathrm{bcr} 3630$

Cite this article as: Criscitiello et al:: Biopsy confirmation of metastatic sites in breast cancer patients: clinical impact and future perspectives. Breast Cancer Research 2014, 16:205 